\title{
Efficacy of Phytotherapy in Oral Mucosites Induced by Chemotherapy and Radiotherapy Phytotherapy in OM really work?
}

\author{
Braz José do Nascimento Júnior ${ }^{1 *}$, Jackson Roberto Guedes da Silva Almeida ${ }^{2}$, Paulo Roberto Ramos ${ }^{2}$ and Elba \\ Lúcia Cavalcante de Amorim ${ }^{3}$
}

${ }^{1}$ Department of Human Morphology, Federal University of the São Francisco Valley, Brazil

${ }^{2}$ Departament of Pharmacy, Federal University of the São Francisco Valley, Brazil

${ }^{3}$ Department of Pharmacy, Federal University of Pernambuco, Brazil

Submission: July 05, 2018; Published: July 20, 2018

*Corresponding author: Braz José do Nascimento Júnior, Federal University of Vale do São Francisco, Department of Human Morphology, Av. José de Sá Maniçoba, N/N, downtown, Petrolina, Pernambuco, Brazil; Tel: 558721016862; Email: braz.jose@univasf.edu.br

\begin{abstract}
Oral mucositis (OM) is a complication of cancer therapy. Because of the associated complications, patients with OM go through decreasing doses or until the suspension of chemotherapy treatment or radiotherapy of head and neck until the improvement of the clinical picture, with that, exposing them the progression of the tumor. Current treatments produce limited results and rely on oral cryotherapy using ice, low-power laser exposure and systemic administration of keratinocyte growth factor (Palifermin).The use of medicinal plants and herbal medicine in the treatment of OM is still little used, but with a tendency to expand and accept the pharmaceutical market. We can conclude that phytotherapy is an expanding market and that, although efficient, needs more research and better acceptance of oncologists and other health professionals. Also some mechanisms of action are still not well understood, therefore, studies are needed that evaluate the long-term effects, in addition to standardized clinical protocols that prove efficacy. An efficient natural product in the treatment of OM should have an anti-inflammatory, bactericidal, antioxidant and healing effect on oral mucosa. In this sense, the search for multi-herbs products can be promising, since the plants together can have superior synergistic effects to the isolated species. However, there are few products in the current market with this profile.
\end{abstract}

Keywords: OM; Phytotherapy; Cancer therapy

Abbreviations: Oral Mucositis (OM); Inducible Nitric Oxide Synthase Enzyme (iNOS); Nitric Oxide (NO); Interleukin 1 beta (IL-1ß); Tumor Necrosis Factor Alpha (TNF- $\alpha$ )

\section{Introduction}

Oral mucositis (OM) is a complication that results from cancer therapy, with a prevalence of 75\%-99\% [1]. Complications due to antineoplastic treatment are associated with factors such as number of chemotherapy fractions, total dose of radiotherapy, interval between sessions, and total time of treatment and also factors related to patients such as age, smoking, oral hygiene index and alcohol [2].

The clinical manifestations most commonly associated with cancer therapy in the oral cavity are OM, osteorradionecrosis, xerostomia, radiation caries, trismus, opportunistic infections, dysphagia, among others [3]. Because of the associated complications, patients with OM go through decreasing doses or until the suspension of chemotherapy treatment or radiotherapy of head and neck until the improvement of the clinical picture, with that, exposing them the progression of the tumor.
Current treatments produce limited results and are based on using ice oral cryotherapy, laser exposure power and low systemic administration of keratinocyte growth factor (Palifermin).The use of medicinal plants and herbal medicine in the treatment of $\mathrm{OM}$ is still little used, but with a tendency to expansion and acceptance of the pharmaceutical market.

Some herbal medicines have been used in treatment, such as Aloe Vera gel. Some patients often use Aloe vera L. topical gel to prevent radiation contact dermatitis and to control esophagitis and OM [4]. Although the mechanism of action is not well established, it is hypothesized that the gel inhibits cyclooxygenase because it has anti-inflammatory properties. The Extract of Hypericum perforatum L. contains in its phytocomplex the borneol and have shown anti-inflammatory and cicatricial activities in $\mathrm{OM}$ in animal models [5,6]. Borneol has an 
antioxidant effect, promoting cellular protection and decreasing iNOS and NO expression [7]. Chamomile (Matricaria chamomilla L.) has been used in the treatment of OM with promising results, reducing tissue levels of IL-1 $\beta$ and TNF- $\alpha$, presenting antiinflammatory activity $[8,9]$.

Honey has been used in the treatment of OM in reducing the frequency of mucositis and associated bacterial infection, but with conflicting results in some studies [10]. Honey in another study showed no statistical significance compared to placebo [11]. The leaves of Camellia sinensis L. are used in an exaggeration, BaxidilOnco $\AA$, with antioxidant action and success in reducing the incidence, severity and duration of $\mathrm{OM}$ [12]. Acacia catechu has been used in mouthwash for its antiinflammatory and cicatricial actions, with promising results [13]. Calendula officinalis has been used in the treatment of OM with a significant reduction in lesion intensity [14].

\section{Conclusion}

We can conclude that phytotherapy is an expanding market and that, although efficient, needs more research and better acceptance of oncologists and other health professionals. Also some mechanisms of action are still not well understood, therefore, studies are needed that evaluate the long-term effects, in addition to standardized clinical protocols that prove efficacy. $\mathrm{OM}$, because it is a frequent complication, requires research that seeks to improve patients' quality of life, reducing pain and the appearance of lesions. An efficient natural product in the treatment of OM should have an anti-inflammatory, bactericidal, antioxidant and healing effect on oral mucosa. In this sense, the search for multi-herbal products can be promising, since the plants together can have superior synergistic effects to the isolated species. However, there are few products in the current market with this profile.

\section{References}

1. Patussi C, Sassi LM, Munhoz EC, Zanicotti RTS, Schussel JL (2014) Clinical assessment of Oral mucositis and candidiasis compare to chemotherapic nadir in transplanted patients. Braz Oral Res 28: 1-7.

2. Bueno AC, Magalhães CS, Moreira AN (2012) Associações entre Fatores de Risco e Complicações Bucais em Pacientes com Câncer de Cabeça e Pescoço Tratados com Radioterapia Associada ou Não à Quimioterapia. Pesquisa Brasileira em Odontopediatria e Clínica Integrada 12(2): 87 93.

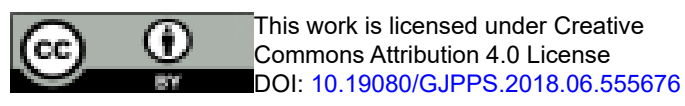

3. Simões CA, Castro JFL, Cazal C (2011) Cândida Oral como Fator Agravante da Mucosite Radioinduzida. Revista Bras Cancer 57(1): 2329.

4. Freitas VS, Rodrigues RAF, Gaspi FOG (2014) Propriedades farmacológicas da Aloe vera L. Burm. f. Rev Bras Plantas Med 16 (2): 299-307.

5. Tanideh N, Namazi F, Tadbir AA, Ebrahimi H, Koohi-Hosseinabadi O (2014) Comparative assessment of the therapeutic effects of the topical and systemic forms of Hypericum perforatum extract on induced Oral mucositis in golden hamsters. Int J Oral Max Surg 43(10): 1286-1292.

6. Nascimento-Júnior BJ, Brito LS, Barros WN, Gonçalves DM, Matos LS, et al. (2017) Anti-inflammatory and healing action of oral gel containing borneol monoterpene in chemotherapy-induced mucositis in rats (Rattus norvegicus). Braz J Pharm Sci 53(3): 1-10.

7. Liu R, Zhang L, Lan X, Li L, Zhang TT, et al. (2011) Protection by borneol on cortical neurons against oxygen-glucose deprivation/reperfusion: involvement of anti-oxidation and anti-inflammation through nuclear transcription factor карраB signaling pathway. Neuroscience 176 : 408-419.

8. Dos Reis PE, Ciol MA, de Melo NS, Figueiredo PT, Leite AF, et al. (2016) Chamomile infusion cryotherapy to prevent Oral mucoisitis induced by chemotherapy: a pilot study. Support Care Cancer 24(10): 4393-4398.

9. Curra M, Martins MA, Lauxen IS, Pellicioli AC, Sant'Ana Filho M, et al. (2013) Effect of topical chamomile on immunohistochemical levels of IL-1 $\beta$ and TNF- $\alpha$ in 5-fluorouracil-induced Oral mucositis in hamsters. Cancer Chemother Pharmacol 71(2): 293-299.

10. Khanal B, Baliga M, Uppal N (2010) Effect of topical honey on limitation of radiation-induced Oral mucositis: an intervention study. Int J Oral Maxillofac Surg 39: 1181-1185.

11. Hawley P, Hovan A, McGahan CE, Saunders D (2014) A randomized placebo-controlled trial of manuka honey for radiation-induced oral mucositis. Support Care Cancer 22(3): 751-761.

12. Carulli G, Rocco M, Panichi A, Chios CF, Ciurli E, et al. (2013) Treatment of Oral mucositis in hematologic patients undergoing autologous or allogeneic transplantation of peripheral blood stem cells: a prospective, randomized study with a mouthwash containing Camelia Sinensis leaf extract. Hematol Rep 5(1): 21-25.

13. Shi Y, Shan J (2009) Observation on the effect of catechin from traditional Chinese medicine on oral ulcer induced by chemotherapy. J Clin Nurs 8(1): 47.

14. Babaee N, Moslemi D, Khalilpour M, Vejdani F, Moghadamnia Y, et al. (2013) Antioxidant capacity of calendula officinalis flowers extract and prevention of radiation induced oropharyngeal mucositis in patients with head and neck cancers: a randomized controlled clinical study. DARU J Pharm Sci 21: 18.

Your next submission with Juniper Publishers
will reach you the below assets
- Quality Editorial service
- Swift Peer Review
- Reprints availability
- E-prints Service
- Manuscript Podcast for convenient understanding
- Global attainment for your research
- Manuscript accessibility in different formats
( Pdf, E-pub, Full Text, Audio)
- Unceasing customer service
Track the below URL for one-step submission
https://juniperpublishers.com/online-submission.php

